\title{
KOVÁCS OLIVÉR
}

\section{Gazellák az iparpolitika tükrében, II.}

Kétrészes tanulmányunk I. része bemutatta, hogy mi tudható közgazdaságilag a gyors növekedésre képes vállalatok (gazellák) természetéről, illetve mi a gyakorlati jelentőségük az európai térben, és mely dinamikus kölcsönhatások befolyásolják az effajta vállalkozói mentalitást. A II. rész a gazellákat a világgazdasági kihívások komplex rendszerébe ágyazza, és arra kíván választ adni, hogy a modern gazdasági kormányzás tényleg feladhatja-e - és egyáltalán, fel kell-e adnia - a semlegesség elvét e vállalatokra koncentráló újfajta iparpolitikai megközelítéssel azért, hogy előmozdítsa a kormányzásba vetett bizalmat erősítő termelékenységi javulást és inkluzívabb növekedést az ipar 4.0 és a digitális gazdaság korában?* Journal of Economic Literature (JEL) kód: L5, L6, O25, O4, 03.

A 2008-as pénzügyi és reálgazdasági válság előrejelzése (pontosabban előre nem jelzése) kapcsán megkérdőjeleződött a közgazdaság-tudomány fỏáramának mindenhatósága, ${ }^{1}$ és szembeötlő a globális liberális rend szerből való kiábrándultság. ${ }^{2}$ A válság és következményei végképp világossá tették, hogy amikor a föbb makromutatók volatilitása alacsony, akkor „kódolódnak” azok a kritikus instabilitások, amelyek a globális kapitalizmus ostorozásához, súlyosabb esetben a politikától való erőteljesebb elforduláshoz, populizmushoz, protekcionizmushoz és szecesszionista törekvésekhez vezet(het)nek. De nem mindegy az sem, hogy ez az időszak régi és/vagy

* A tanulmány a Bolyai János kutatási ösztöndíj támogatásával és az Innovációs és Technológiai Minisztérium ÚNKP-19-4-NKE-2 kódszámú Új Nemzeti Kiválóság Programjának szakmai támogatásával készült.

${ }^{1}$ Ezt járja körbe Kovács [2019].

${ }^{2}$ A globális liberális rendszer súlyos problémáiról lásd Wolf [2019], ehhez kapcsolódóan a globalizáció súlyos következményekkel járó mellékhatásairól lásd Jacobs-Mazzucato [2016] gondolatébresztő kötetét, a legújabb válságvárakozások kapcsán lásd az angol jegybank korábbi elnökének, Lord Mervyn Kingnek a beszédét (King [2019]).

Kovács Olivér a Nemzeti Közszolgálati Egyetem Közgazdaságtani és Nemzetközi Gazdaságtani Tanszékének tudományos fömunkatársa, az ICEG European Center tudományos munkatársa (e-mail: Kovacs.Oliver.Istvan@uni-nke.hu,web: http://oliverkovacs.com).

A kézirat első változata 2019. december 20 -án érkezett szerkesztőségünkbe.

DOI: http://dx.doi.org/10.18414/KSZ.2020.2.181 
új kölcsönhatások dinamikus konfigurációjaként jön létre: például átszövik-e tartósabb tendenciák, mint ahogy az egyébként megfigyelhető a termelékenység szekuláris stagnálásában és a gyengülő gazdasági növekedés inkluzív élének egyre látványosabb tompulásában (kirekesztő növekedés) - ahogy erröl a tanulmány I. részében szóltunk.

Ezért kézenfekvőnek tünik, hogy nagy szerep hárul a gyors növekedésü (jobbára magasabb termelékenységgel és foglalkoztatással jellemezhetö) gazellákra, amelyek egyszersmind a társadalmi-gazdasági innovációs ökoszisztéma dinamizmusának fontos szereplői, a rugalmasság (resilience), a rendszer sokktűrő képességének szavatolói. Tanulmányunk I. részéből az is kiderült, hogy a gazellák természete nem önmagában, hanem szélesebb összefüggésben értelmezhető és fejthető fel.

Kétségtelen, hogy a rendszer sokktürő képességének javítása fontos szempont, kialakítása azonban gigászi feladat, lévén hogy az integrált világgazdaság szinte felfoghatatlanul (modellezhetetlenül) komplexszé vált: a sokféleség, az egyidejüség, az intenzív hálózatosodás korát éljük, amit aszimmetrikus interdependenciák, a mellékhatások globalizálódása, nemlineáris kölcsönhatások, irreverzibilis viselkedések jellemeznek, s amiben intenzívebben találkozni a makroszférát elérő mikroszintü ingadozásokkal (pozitív és negatív visszacsatolásokon keresztül), valamint a kumulatív okság jelenségével. Következésképpen nincs a folyamatoknak egyetlen felelösük. De nincs olyan szervezet vagy egyén sem, amely vagy aki tudományosan megalapozottan át tudná látni az egész rendszert, és képes volna ex ante feltárni az egyes gazdaságpolitikai intézkedések (kölcsön)hatásainak teljes vertikumát. Ezért hát nincs üdvözítő és standard iparpolitika sem, amely a digitális transzformáció és az ipar 4.0 korában a tervezetteknek megfelelően idézné elő a termelékenység látványos emelkedését, és erősítené a növekedés inkluzívabb természetét. Továbbá, a komplexitást alázattal kezelő közgazdász nem bocsátkozhat jóslásokba a következő nagy válság méretéről és kitörésének várható idejéről - mint ahogy a legnagyobb válságot 2023-ra jósló legfrissebb bestsellerek írói teszik (lásd Friedrich-Weik [2019]). Legfeljebb csak körvonalazni lehet bizonyos - a gazellák fejlödése szempontjából kiemelten jelentős - komplex kihívások rendszerét, amely tulajdonképp előhírnöke egy következő válságnak: 1. klímaváltozás, 2. szekuláris stagnálás, 3. demográfiai kihívások és krónikus egyenlőtlenségek, 4. vállalatok közti egyenlőtlenségek, 5. a pénzügyi szféra és a reálgazdaság megtört harmóniája, valamint 6 . a negyedik ipari forradalommal kapcsolatos bizonytalanságok széles köre.

Jelen tanulmányban először ezeket a területeket vesszük végig, kiegészítve azzal, hogy melyek a kölcsönhatások dinamikus konfigurációjának bizonyos tartós és a szakpolitika-alkotás szempontjából megszívlelendő jellemzői. Célunk, hogy az I. rész tanulságaira építve képesek legyünk általánosabb elméleti és empirikus megállapításokat tenni az európai gazellák természetéről; valamint a gazellákra vonatkozó iparpolitikai összefüggések kapcsán megválaszoljuk alapvető kutatási kérdésünket: valóban feladhatja-e (és egyáltalán, fel kell-e adnia) a modern gazdasági kormányzásnak a semlegesség elvét e vállalatokra koncentráló újfajta iparpolitikai megközelítéssel azért, hogy elősegítse a kormányzásba vetett bizalmat erősítő termelékenységi javulást és inkluzívabb növekedést az ipar 4.0 és a digitális gazdaság korában? 


\section{A kölcsönhatások dinamikus szerkezete}

\section{Klímaváltozás}

A gazellák fenntartható működéséhez szükséges invesztíciók és tudásbázis kialakításához ösztönző és támogató programok szükségesek, hogy a zöldnövekedési paradigmára - ökohatékonyságra (nagyobb hozzáadott érték alacsonyabb környezetterheléssel) - való átállás meggyorsítható legyen a gazellák közremüködésével. Az európai mikrovizsgálatok már ma megerősítik azt a feltételezést, hogy a zöldnövekedésre történő átállásban meghatározó a gazellák helyzete, a zöldtechnológiákat nyújtó cégek növekedési képessége megnőtt. Ökohatékony innovációval gazellává válhatnak a cégek, és nagy valószínűséggel fenntarthatóságot érhetnek el (Colombelli és szerzötársai [2019]). Ez különösen fontos, mérlegelve a klímaváltozás hosszabb távú negatív hatásait, amelyeket a gazdasági kormányzásnak valamilyen módon meg kell próbálnia mérsékelni (például a klímaváltozás a szegényebb régiókat érinti erőteljesebben, ezáltal még tovább növekszik az extrém szegénységben élök száma, illetve súlyosbodnak az egyenlőtlenségek - Burzynski és szerzőtársai [2019]). Teret nyer az ökohatékonyság növelésének, a klímaváltozás elleni küzdelemnek $s$ ha úgy tetszik, a minőségi növekedésnek a feladata (az állami, a piaci, a civil szféra részéről egyaránt).

\section{Szekuláris stagnálás}

A teljes tényezőtermelékenység (total factor productivity, TFP) - amely mutató minden tökéletlenségével együtt leképezi egy-egy ország innovációs képességét - világviszonylatban és szekuláris értelemben romlik (Teulings-Baldwin [2014]). Az Egyesült Államok és az Európai Unió átlagos növekedési rátája 4-5 százalék volt az 1950-1960-as években, a hetvenes évektől kezdve lassulni kezdett, és a 2010-es évekre már csak 2 százalék körüli a potenciális növekedés üteme. Az is látszik, hogy a mai gyengébb termelékenységi eredményekhez hússzor több kutatóra van szükség, mint az 1970-es éveket megelőzően. Sokan úgy vélik azonban, hogy a szekuláris stagnálás voltaképp csak mérési módszertanunk tökéletlensége miatt merül fel, mert az képtelen a minőség terén tetten érhető javulásokat megragadni, ily módon méréseink rendre a termelékenység romlásáról tájékoztatnak. Byrneés szerzötársai [2016] szerint az Egyesült Államokkal kapcsolatban a mérési hibának ezen magyarázata nem áll: a TFP tartósan és nem csupán az információtechnológiai (IT), hanem a hagyományos szektorokban is romlik. Az OECD és a Nemzetközi Valutaalap közös kutatási projektje is arra jutott, hogy bár létezik mérési hiba (például a GDP mérése terén és a GDP-hez mért termelékenység kapcsán), annak korrigálásával sem vagyunk képesek megmagyarázni a széles körben megfigyelhető romlást a teljes vagy a többtényezős termelékenységi rátában (Ahmad és szerzötársai [2017]).

A szekuláris stagnálás tehát rendszerszintü, és inkább a technológiai-gazdasági paradigmaváltások rendszerszemléletű elméletével értelmezhetö. ${ }^{3}$ A technológiai-gazdasági

\footnotetext{
${ }^{3}$ Az egymást váltó paradigmákról és jellemzőikről lásd Kovács [2015] 107-110. o.
} 
paradigmaváltás az információs forradalomra építve immáron a szolgáltatások dominálta tudásgazdaságra való átállást jelenti (amelyben kezd kibontakozni az úgynevezett 4. ipari forradalom a digitális gazdaság széles körű elterjedésével). A technológiai innovációk mellett megnőtt a szerepe a nem technológiai (szervezeti, marketing-, folyamat-) jellegü újításoknak. Ezeknek elsősorban minőségi - menynyiségileg nehezen mérhető - termelékenységi hatásuk van (növekvő fogyasztói lojalitás, érzelmi kötődés, vásárlói kényelem és jobb felhasználói élmény). A termelő szektor is egyre több szolgáltatással egészíti ki termékportfólióját, így szükségképpen az alacsonyabb termelékenységi javulást alapozzák meg. Miközben a társadalmi-gazdasági rendszer egyre komplexebbé vált, a termékek és szolgáltatások is egyre szofisztikáltabbak lettek, amelyek nagyobb kockázatot jelentő, erőteljesebb kutatás-fejlesztési és innovációs intenzitást feltételeznek. Nem meglepő, hogy az effajta kockázatosabb reálgazdasági innovációkba történő invesztíciók intenzitása lecsökkent (például nőtt a megtakarítás vagy a készpénztartási hajlandóság). Elég csak azt a mintázatot figyelembe vennünk, hogy az ipari vállalatok 1980 és 2006 között mindinkább növelték készpénzeszköz-arányukat, ${ }^{4}$ mert a cash-flow a bizonytalanabb környezetben sokkal volatilisabbá vált.

A szekuláris stagnálás tehát endogén módon alakult ki, nem externális sokkról van szó; s benne szerepet játszik a gyors növekedésủ innovatív vállalkozások tendenciaszerü teljesítménygyengülése és számosságuknak csökkenése is. Az elmúlt több mint két évtized amerikai tapasztalatai is ezt erősítik: az Egyesült Államokban a magas növekedésre képes fiatal és érettebb korú cégek aránya látványosan csökkenni kezdett a kilencvenes évek közepétől (a 2000-es évektől kezdve pedig még intenzívebben - Decker és szerzőtársai [2016]). A gazellák transzformatív ereje tehát a 2000-es évektől kezdődően meggyengült (legalábbis ami a foglalkoztatásbővítő szerepüket illeti). A paradigmaváltás kiteljesedésével párhuzamosan a gazellák növekedési folyamatának természete is átalakult: mára a gyors növekedést elsősorban az üzemi eredményben realizálják, ezt követi az eszközállomány, majd az értékesítések további növekedése, és esetleg majd csak a folyamat végén lehet foglalkoztatásbővítést regisztrálni. A tudásgazdaság és a digitalizáció elörehaladtával fokozatosan megcsappanni látszik a gyors növekedésủ vállalatok ereje és száma (nem csupán a csúcstechnológiai, hanem a többi ipari szektorban és a szolgáltatások terén is). ${ }^{5}$ Nagy a bizonytalanság - amit a kibontakozó globális kereskedelmi háború csak súlyosbít, ennélfogva nem lepődünk meg azon, hogy a 2008-as válság óta eltelt több mint egy évtizedben a gyengülő világgazdasági növekedés hátterében az üzleti szféra mérséklődő költési hajlandósága áll (például gépekre és berendezésekre), a keresleti oldalon pedig a fogyasztók tartós áruk iránti keresletének megcsappanása. Radikális bizonytalanság uralkodik, aminek egyik oka az egyenlőtlenségek megnövekedése és megoldatlansága.

\footnotetext{
${ }^{4}$ Az Egyesült Államok esetében lásd Bates és szerzőtársai [2009], Európa kapcsán pedig Bachurov [2013].

${ }^{5}$ Fernald [2015] bemutatja, hogy a magas technológiai hozzáadott értéket előállító szektorokban tevékenykedő gazellák visszaesése a szektorok termelékenységének érezhető romlásával járt együtt.
} 


\section{Demográfiai kihívások és krónikus egyenlötlenségek}

Bár elvitathatatlan, hogy a globalizációnak köszönhetően az emberiség által létrehozott anyagi javak 80-90 százaléka az elmúlt 90-100 év terméke, valamint a felgyorsult és irreverzibilis globalizációnak köszönhetöen emberek milliói emelkedtek ki a szegénységből, ${ }^{6}$ súlyos demográfiai kihívással és fokozódó egyenlőtlenséggel nézünk szembe, ami a gazdasági kormányzáshoz szükséges bizalmi infrastruktúrán ejt komoly sebeket, sok helyütt politikai instabilitást kódolva a rendszerbe.

Az OECD-országokban a medián háztartási reáljövedelem stagnált az elmúlt 20-25 évben. Ebből fakadóan több szempontból vált egyenlötlenné a növekedés. Nemcsak az igaz, hogy mára egy tipikus OECD-ország gazdasági növekedésének közel harmadát a régiók csupán 5 százaléka adja, hanem az is, hogy nőtt a vagyoni és jövedelmi egyenlötlenség. Ez a növekedés nagyon magas fokú földrajzi koncentrálódására utal, tehát nem véletlen, hogy a gazellákat is inkább a nagy lélekszámú fövárosokban regisztrálták (Marchese [2016]). A főváros elszívó hatást fejt ki a vidékre, annak esetleges kiürülését, lemaradását előidézve. Az a helyzet alakult ki, hogy a leggazdagabb 10 százalék tízszer többet keres, mint a legszegényebb 10 százalék (az 1980 -as években még csak hétszeres volt a szorzó), illetve a háztartások leggazdagabb 1 százaléka az OECD-háztartások összvagyonának 19-20 százalékát birtokolja, míg a legszegényebb 40 százalék csak a 3 százalékát. A dinamikus elszegényesedés jelen van, zsugorodik a középosztály (OECD [2019]), a fejlett országokban a szegénység mérséklése terén csak igen csekély elörelépés történt 1990 és 2013 között (Ravallion-Chen [2017]), sőt a 2008-as válság óta a folyamat le is állt.

Egyfelől tehát az aktív munkaképes korú népesség csökken Európában, amivel párhuzamosan a fizetőképes és az innovációk elterjedésében kulcsszerepet játszó széles középosztályi bázis sincs már meg. Ez azt jelenti, hogy a társadalmi csoportok sérülékenységi fokában is rendkívül nagyok lettek a különbségek. A válság hatására a rendelkezésre álló reáljövedelem számos országban - így még az EU motorjaként funkcionáló Németországban is - csökkenni kezdett, a középosztály pedig fokozatosan elszegényedik, mérete zsugorodik. Az Európai Unióban nagy szükség van a gazdasági növekedés inkluzívvá tételére, az egyének kibontakozási lehetőségeinek fokozására, az egyenlötlenségek tompítására, ${ }^{7}$ hiszen még azokban az országokban is nagy a kihasználatlan emberi tőke és kapacitás, ahol a munkanélküliségi ráta viszonylag alacsonynak tekinthetö. Hivatalosan összesen 20,9 millió munkanélkülit regisztráltak 2016-ban az EU-ban. Mindazonáltal, ha ehhez hozzávesszük az alulfoglalkoztatott részmunkaidősöket (9,5 millió fö), illetve azokat, akik nem vállaltak munkát

${ }^{6}$ 1970-ben még a Föld 3,96 milliárdos népességéből 2,2 milliárd fő élt extrém szegénységben, azaz napi 1,9 dollárból, 2015-ben a 7,35 milliárdos népességből már „csak” 705,5 milliónyian (https:// ourworldindata.org/extreme-poverty/).

${ }^{7}$ Az Eurostat adatai alapján látható, hogy az EU28-ban tartósan romlik a jövedelemegyenlőtlenség. Az uniós lakosság legjobban kereső ötöde 2010-ben 4,9-szer többet keresett, mint a jövedelmi skála alsó ötödébe tartozók. 2018-ra ez az érték megközelítette az 5,2-et. A szegénység vagy társadalmi kirekesztés kockázatával szembesülők száma sem mutat látványos javulást (2010-ben 117 millió, 2018-ban még mindig 110 millió). 
(8,8 millió fö), továbbá azokat, akik munkát keresnek, de nem tudnak rövid időn belül munkába állni (2,3 millió fö), akkor a helyzet súlyosabb: közel 42 millió ember nem talált képzettségének megfelelő munkát az EU-ban (még 2018-ban is a munkanélküliek 43 százaléka több mint egy éven át volt állás nélkül). A foglalkoztatási trend azóta ugyan javul, a számok mögötti struktúra azonban továbbra is arról árulkodik, hogy nő a magasan, illetve az alacsonyan fizetett munkahelyek száma, miközben a közepes jövedelműeknek megfelelö munkahelyek száma gyors iramban csökken, ezzel növelve a prekariátus társadalmi réteget (Standing [2016]), amelynek tagjai bár ideig-óráig van munkájuk, de - szinte folyamatos létbizonytalanságban élnek. Ez a körülmény bizonyosan negatívan befolyásolja a magas növekedésű gazellák számát, illetve a meglévők foglalkoztatásra gyakorolt hatását. ${ }^{8}$

Az elmondottak rávilágítanak arra, hogy az emberi tőke általános minőségi színvonalának emelésére és folyamatos utánpótlására, illetve a felhalmozott tudás kiaknázására nagyobb az igény, mint valaha. A gazellák ama képessége, hogy egy nagyobb sebességü növekedést követő, érzékelhető lassulásból újra képesek magasabb növekedési dinamikára kapcsolni, arra utal, hogy a gazellák többsége inkább tudásbővítést (explorative knowledge creation) végez - teszi ezt úgy, hogy föleg immateriális eszközállományra épít, azaz emberi tőkére, tudásra (hallgatólagos tudásra is) a technológiai és nem technológiai innovációi megalapozásához -, mintsem hogy a már meglévő tudás folytonos kiaknázására (exploitative knowledge creation) törekedne (Colombelli és szerzőtársai [2014]). A demográfiai helyzet ezért nagyon is hat a gazellákban rejlö potenciál kihasználhatóságára. Természetesen vannak, akik az egyenlötlenségek csökkentésének letéteményeseiként is tekintenek e vállalati létformákra.

Ugyanakkor a gazellákkal kapcsolatos szakpolitikai diskurzus résztvevőinek az empirikus irodalomból látniuk kell azt, hogy igen komoly átváltás lehet az inkluzivitás és a termelékenység megtámogatása között. A gyors növekedésű vállalkozások nem mindig csökkentik a társadalmi egyenlötlenségeket. Sőt a magasabb termelékenységi dinamikát rendszerint növekedési gócokban, hatékonyabb innovációs ökoszisztémában realizálják (például föváros, nagyvárosok). S az e növekedési gócpontokba települö vállalatok komoly elszívó hatást gyakorolnak a vidéki régiók tehetségeire. ${ }^{9}$ Nem beszélve arról, hogy még az aktív munkaerőpiaci szakpolitikákkal - amelyek az inkluzivitást hivatottak dedikáltan elösegíteni (például bértámogatási sémák, a közmunkaprogramok, a mikrovállalkozások vagy a független munkavállalók támogatása stb.) - kapcsolatos legújabb ismeretünk is az, hogy némi eredmé-

\footnotetext{
${ }^{8}$ Eurostat-adatokból kitünik, hogy a gazellák összes vállalkozáson belüli aránya azokban az európai országokban lett a legkisebb 2015-re, ahol egyébként a középosztály zsugorodásának foka a legnagyobb (Ausztria, Románia). Németországban és még a skandináv országokban is (Svédország, Finnország) megfigyelhető, hogy a gazellák aránya csökken, és a középosztály is szignifikánsan csökken. A középosztály zsugorodását lásd még: https://www.eurofound.europa.eu/de/publications/blog/ europes-shrinking-middle-class, Vacas-Soriano-Fernández-Macías [2017].

${ }^{9}$ ERC [2019] több mint 6 millió cég tapasztalatait vette alapul az 1997-2013-as időszakban. Megállapította, hogy egy régióban a gazellák előfordulásának 1 százalékos növekedése átlagosan 0,35 százalékkal csökkenti a foglalkoztatást. Ez körülbelül 122 ezer munkahely nettó elvesztését jelentette.

Lee és szerzötársai [2015] országkeresztmetszeti empirikus vizsgálata szerint a nagyvállalati dominancia a növekedés lassulásához, az egyenlőtlenségek fokozódásához vezetett.
} 
nyességet is inkább csak az eleve magasabb (GDP-) növekedésủ időszakban és alacsonyabb munkanélküliségi trend mellett sikerült elérni (Levy-Yeyati és szerzötársai [2019]). Mindezek tükrében a „gazellapolitika” terén rendkívül korlátos a felelősségre törekvő modern állam mozgástere.

\section{Vállalatok közti egyenlötlenségek}

A gazellák a társadalmi-gazdasági dinamizmus fontos letéteményesei megannyi dimenzióban (foglalkoztatás, a tanulási képesség erősítése, abszorpció- és diffúzióserkentő szereplők stb.). Miközben világgazdaságunk soha nem látott mértékü digitalizációt és integráltságot mutat, a fejlett országok - így az Európai Unió tagországai - innovációs dinamizmusa arról árulkodik, hogy nemcsak a jövedelem- és vagyoni egyenlötlenségek növekszenek, de a vállalatok között is növekvő és krónikus egyenlötlenség jellemzi a termelékenységnövekedés dinamikáját.

A téma nem új, csak új köntösben és sokkal összetettebben merül fel újra. Theodore Roosevelt már több mint száz esztendeje kifejtette abbéli aggodalmát, hogy a vállalati óriások bizonyos köre képes lehet átvenni az amerikai gazdaság feletti teljes kontrollt; ${ }^{10}$ így különböző privilégiumok biztosítása számukra csak arra jó, hogy aláássák az egyenlő lehetőségek (equability) biztosításának elvét. Vagyis tartott a verseny mérséklődésétől, potenciális megszűnésétől. Az alapvető szakpolitikai dilemma tehát a következő: miképp támogassuk a vállalkozókat/vállalkozásokat úgy, hogy az a lehető legtöbb társadalmi haszonnal járjon, miközben minimalizáljuk a monopolisztikus járadékszerzés lehetőségét és bebetonozódását.

A mai digitális gazdaság korában újra napirenden van a monopóliumok dominanciájának (a győztes mindent visz) kérdése. Az információs-kommunikációs technológiára (IKT) építő, szolgáltatások dominálta hálózatos tudásgazdaságban az IKT törvényszerűségeiből fakadóan könnyebb monopolisztikus viszonyokat kialakítani és fenntartani, azaz a piacok megtámadhatóságának baumoli elve (Baumol és szerzőtársai [1982]) veszített eredeti erejéből ${ }^{11}$ (itt most nem a szabályozás miatt meglévő belépési költségről van szó - amelynek a leépítéséért szállt síkra számos szakpolitikai javaslat az elmúlt években -, annak drasztikus leépítése már nem sarkallná a belépni kívánkozó kicsiket kockázatosabb, ám átütőbb innovációkra).

Nemcsak az igaz, hogy a fejlett országokban az üzleti vállalkozások átlagos életkora évtizedek óta szinte folyamatosan növekszik (Hathaway-Litan [2014]), hanem

\footnotetext{
${ }^{10}$ Roosevelt híres trustbusters felfogásáról lásd Atkinson-Lind [2018].

${ }^{11}$ A Moore- és a Gilder-törvényekből jól ismert - jelen esetben a Bob Metcalfe nevéhez füződő hálózati hatás lényeges: vagyis, hogy a hálózat értéke négyzetesen arányos a hozzá csatlakozó tagok számával. A leggyakrabban emlegetett példa a telefonhálózat: ha a rendszerhez egy új tag csatlakozik, akkor minden már bent lévő tag telefonja értékesebb lesz, hiszen eggyel több emberrel lehet kommunikálni. Gyakorlatilag a digitális platformok, alkalmazások (applikációk) és az adathalmazok (Big Data) tekinthetők manapság az új természetes monopóliumok színtereinek, ahol egy cég is domináns lehet (például PayPal). Az utóbbi szolgáltatást nyújtó cég alapítója, Peter Thiel szerint a verseny ma már nem elsődleges („a verseny a veszteseknek szól” - lásd Thiel [2014]).
} 
az is, hogy eközben a gazellák üzleti vállalkozásokon belüli aránya is mérséklödik. ${ }^{12}$ Régen pedig olyan nagy formátumú gondolkodók, mint Ronald Coase vagy Hal Varian is úgy gondolták, hogy az internet (és általában a digitalizáció) révén csökkenni fognak a tranzakciós költségek, ilyesformán pedig a vállalatoknak könynyebb lesz nagyobbakká válniuk (Coase [2015]). Nem így történt. Ebből is kitűnik egyébként, hogy a gazellák fiatal kisvállalkozás jellege csupán mítosz. Ez tünete a mai tudásgazdaságnak és a kiépülő (ipar 4.0-val füszerezett) digitális gazdaságnak, amikor az automatizálás a munkahelyteremtés nélküli növekedés korszakát még inkább megalapozza. ${ }^{13} \mathrm{Ez}$ minimum két dolgot rejt magában.

1. A mai nagyvállalatok a klasszikus dimenzióknak már nem mindegyikében számítanak nagynak (nagy társasági vagyon, magas foglalkoztatás, gazdag helyi kapcsolatrendszer), hanem inkább piaci kapitalizációban, piaci részarányban tekinthetők erősnek. Nagy domináns vállalatokat egyre inkább csak másik nagyvállalat szoríthat meg és válthat föl; az ambiciózus és gyors növekedésủ vállalatok száma is csökken, és azokon belül egyre kevesebben képesek valóban naggyá növekedni. Vagyis változóban vannak a be- és kilépési korlátok, a piaci szereplők is képesek „intézményes” korlátokká válni. Kaya-Persson [2019] például bemutatta, hogy a gazellák növekedésük fenntartása érdekében megpróbálnak ugyan már piacon benn lévő cégeket felvásárolni, de a kiszemelteket sokszor nagyvállalat szerzi meg előlük, hogy a gazella még véletlenül se legyen képes „,felnőni” melléjük és veszélyeztetni a nagyvállalati profitot. Mindez azt is involválja, hogy míg korábban a gazellák többnyire már meglévő nagyobb vállalatoktól eltávozó, tapasztalt munkavállalók által indított vállalkozások voltak (Shuman és szerzötársai [1985]; Feeser-Willard [1989]), addig mára ez a mintázat megfakult. Ez a rendszerben lévő bizonytalanságra, a nagyvállalati túlsúlyt kódoló szélesebb (országhatárokon túlmutató) innovációs ökoszisztéma természetére irányítja a figyelmet.

2. A gazellákat tanulmányozva nem tekinthetünk el a környezettől, vagyis a mai digitális korban szaporodnak az önfoglalkoztató mikro- és kisvállalkozások, ezzel pedig a foglalkoztatásbővítés-alapú megközelítésük elveszti létjogosultságát (például a 2012-es bázisévhez képest 2016-ban 110 százalék volt az önfoglalkoztatási ráta Hollandiában, 104 százalék Finnországban, Franciaországban és az Egyesült Királyságban - lásd $O E C D$ [2017]). Az önfoglalkoztatók egyre növekvő mértékben dolgoznak

${ }^{12}$ Érdemes megnézni az EU motorjául szolgáló országok (Franciaország, Németország) adatait. Franciaországban a gazellák aránya 2008-ban még 7,7 százalék volt, 2012-ben már csak 5,5 százalék. Németország esetében a 2007-es év teljesítményét 100 százaléknak véve, a létrehozott vállalkozások aránya 2011 első negyedévében 96 százalék, míg 2017 első negyedévében már csak 80 százalék volt. Eközben a megszünések száma csökkent (2011: 100,38 százalék; míg 2017-ben már csak 89,45 százalék a 2007-es bázisévhez viszonyítva - OECD.Stats).

${ }^{13}$ Az OECD-országokban az elmúlt 20-25 évben a medián jövedelem stagnált. A stagnáló bérek az innováció, a tudásba fektetés, az átképzés markáns ellenösztönzői, s most nagyon sokaknak kellene magasabb képzettséget szerezniük ahhoz, hogy helyt tudjanak állni másutt (a munkahelyeknek például Kínában 77 százaléka, az Egyesült Államokban 47 százaléka, míg Európában körülbelül 54 százaléka váltható ki robotikával/automatizálással) (Kovács [2017]). Ha pedig nem tudják a munkavállalókat másutt felszívni - mert jobban át kellene képezniük magukat ahhoz, hogy az automatizált/ számítógépesített és ezért komplexebb munkakörökhöz felnőjenek (Spitz-Oener [2006]) -, akkor az amúgy is eladósodott magán-/háztartási szektor válságos helyzettel nézhet szembe. 
be nagyvállalatokhoz (Îrországban az üzleti vállalkozások több mint fele szerződtet önfoglalkoztatókat). ${ }^{14}$

Az infokommunikációs szakembereket alkalmazó vállalatok százalékmegoszlása azt mutatja (1. táblázat), hogy az IKT-diffúzió súlypontja eltolódik a nagyvállatok javára. Továbbá, az is egyre inkább bizonyítást nyer, hogy aki a globális élvonalba került, az tartósan ott is tud maradni. Ma már a nagyvállalatok az első számú foglalkoztatók az EU-ban (az összes foglalkoztatott 33 százalékát adják, 29,2 százalékát pedig a mikrovállalkozások), és míg 50 százalékuk keres IKT-specialistát, addig a kis- és középvállalkozások esetében ez a szám alig éri el a 8-10 százalékot. 2008 és 2016 között például az 1. táblázatban is feltüntetett EU-országok mindegyikében kimutatható volt, hogy a közepes méretü vállalkozások aránya csökkent, a mikrovállalkozásoké pedig csak enyhén nőtt (ez azért baj, mert a közhiedelemmel ellentétben nem mindig a nagyvállalat termelékenyebb, a vezetö kis- és középvállalatok igen gyakran még termelékenyebbek - lásd OECD [2018]).

\section{1. táblázat}

Az infokommunikációs szakembereket alkalmazó vállalatok százalékaránya (a pénzügyi szektor vállalatai nélkül)

\begin{tabular}{lccc}
\hline & 2012 & 2015 & 2017 \\
\hline 10-249 fö foglalkoztatott & & & \\
\hline Németország & 19 & 19 & 17 \\
Ausztria & 30 & 22 & 21 \\
Magyarország & 29 & 24 & 26 \\
Egyesült Királyság & 29 & 21 & 20 \\
Franciaország & 13 & 15 & 16 \\
\hline 250 fönél több foglalkoztatott & & & \\
\hline Németország & 83 & 82 & 77 \\
Ausztria & 87 & 89 & 87 \\
Magyarország & 66 & 82 & 82 \\
Egyesült Királyság & 81 & 71 & 77 \\
Franciaország & 71 & 77 & 71 \\
\hline
\end{tabular}

Forrás: Eurostat.

Egyenlötlenség van tehát a vállalatok között is, ami a termelékenység növelhetősége szempontjából további szakpolitikai beavatkozást igényelne (ez igaz a termelő és szolgáltató szektorbeli vállalatokra is, utóbbiak esetében a teljesítménybeli különbség még

\footnotetext{
${ }^{14} \mathrm{https} / /$ www.closecommercialfinance.ie/news-and-insights/survey-findings-support-freelanceboom-throughout-ireland.
} 
nagyobb - lásd Andrews és szerzőtársai [2016]). ${ }^{15}$ Ez az egyenlőtlenség állhat többek között az új digitális diffúzió lassúsága mögött.

Az ipari termelöi szektorbeli cégek (10 főt vagy többet foglalkoztatók) esetében is inkább a stagnálás jele látszik. 2012-ről 2016-ra a következő arányokkal találkozunk: Németország (2012: 26 százalék, 2016: 25 százalék), Ausztria (2012: 35 százalék, 2016: 35 százalék), Magyarország (2012: 28 százalék, 2016: 26 százalék), Egyesült Királyság (2012: 30 százalék, 2016: 26 százalék) és Franciaország (2012: 16 százalék, 2016: 17 százalék). A globális vezető és a többi lemaradó (alacsony vagy stagnáló termelékenységü) cégek termelékenysége közötti eltérés csökkentése újabb összetett problémát is rejt magában.

1. A szakpolitikának figyelembe kell vennie, hogy van a rendszerben egy zombivállalat-jelenség, amikor a termelékenyebb és innovatívabb nagyvállalatok már nem szorítják ki a nem túl termelékeny és innováció szempontjából is gyengén szereplö vállalatokat, hanem azok tovább élnek (többek között állami támogatások és különféle kis- és középvállalkozást támogató politikák révén). Nemcsak az igaz, hogy a piacra lépő vállalatok arányában csökkenő tendencia érvényesül, hanem az is, hogy egy hatékony versenyközegben egyébként a piacról már rég kilépő vagy megszünő cégek tovább tudnak úgy létezni, hogy az átlagos termelékenységük tartósan gyengül. ${ }^{16}$ Vagyis az idők folyamán könnyebbé vált a mai gazdasági-társadalmi innovációs ökoszisztémában a gyengébb vállalkozásoknak talpon maradniuk mindenféle kényszerítő adaptáció és technológiai újítás nélkül. ${ }^{17}$ Ennek a folyamatnak a makroszkopikus hatása az, hogy a termelékenység átlagos javulását mindinkább lefelé húzzák ezek a vállalkozások. A bérszínvonal stagnálásával párhuzamosan az alacsony infláció, a lassú növekedés, az alacsony beruházási aktivitás környezetét alapozzák meg, amelyben az egyenlőtlenségek jobban kiéleződnek a jövedelmi és vagyoni dimenzión

${ }^{15}$ Lényeges, hogy a fejlett világban (így például az Egyesült Államokban, az euróövezet országaiban vagy például az Egyesült Királyságban) a 2000-es évek elejétől kezdődően leállt az IKT diffúziója (Cette és szerzőtársai [2015]). Vagyis az uralkodó innovációs ökoszisztéma inkább gátolja, mintsem elősegítené az infokommunikációs technológia elterjedését, azon keresztül pedig az ipar 4.0 technológiák és szolgáltatások diffúzióját.

${ }^{16}$ Európában a 2008-2009-es válságra adott válaszreakció (monetáris lazítás, mennyiségi csillapítás) megnövelte a zombicégek arányát (BIS [2017] 13. o.), vagyis azoknak a nem pénzügyi vállalkozásoknak az arányát, amelyek nem képesek folyó bevételeikkel fedezni az adósságaik után fizetendő kamatterheket. A zombijelenség egyébként Szingapúrban is létezik, holott sokáig élvonalbeli gazellakeltető ökoszisztémaként tekintettek az országra. 2017-ben a technológiai startupoknak már csak 8 százaléka volt gazella, és azoknak mindössze harmada volt képes innovációkkal új termékeket és szolgáltatásokat piacra vinni, a nagy többségük imitátor (másol és helyi viszonyokhoz adaptál) (lásd erről bővebben Vasagar [2017]).

${ }^{17}$ Az inkubátorok eredményessége sokszor meglehetősen kiábrándító (lásd Mas-Verdú és szerzötársai [2015], illetve Amezcua és szerzőtársai [2013], akik 178 inkubátor esetét tekintették át). Továbbá, az érem másik oldala, hogy míg sokáig életben tudnak maradni a nem oly innovatív és termelékeny vállalkozások, addig a vállalkozói kedv viszont stagnálni látszik: azaz nem növekszik szignifikánsan azok aránya, akik vállalkozásindításra reális esélyt látnak. Ha arra vagyunk kíváncsiak, hogy a 18-64 éves népességen belül mekkora azok aránya Európában, akik a következő három esztendőben új vállalkozást szándékoznak indítani, akkor azt látjuk, hogy a 2002. évi 7,4 százalék 2008-ra tovább apadt 6,8 százalékra. Arányuk 2016-ban az EU motorjának számító Németországban is csak 6,2 százalék volt, miközben az európai átlag 11,9 százalék (lásd a Global Entrepreneurship Monitor kiadványait). 
túl is (például készségek, képességek), ami visszacsatol a termelékenységnövekedés alacsony üteméhez (McGowan-Andrews [2015]). Ennek egyik mögöttes hajtó mechanizmusa az az európai kontinensre jellemző elszántság, hogy a komoly foglalkoztatási problémák miatt a növekedést a korábbinál is inkluzívabbá kell tenni, amelyben óriási szerepet kap a kis- és középvállalkozási szektor.

2. A jelenlegi gazdasági környezet a bizonytalanság melegágya, aminek hatására a befektetők kockázatkerülőbbé válnak (túl azon, hogy sokszor a vállalati menedzserek stratégiái vagy a politikusok valós szándékai a müszaki haladásénál is nagyobb bizonytalanságokat rejtenek). Ennek következtében a tőke egyre csekélyebb mértékben áramlik a termelékenyebb - ám az innováció miatt kockázatosabb, elsősorban immateriális eszközállománnyal rendelkezö új, innovatív és gyors növekedésre képes - vállalkozásokhoz, és egyre nagyobb mértékben vándorol a nagyobb nettó értékü, ám nem feltétlenül termelékenyebb vállalatokhoz. ${ }^{18}$ Mindezeket az országkeresztmetszeti vállalati szintű empirikus vizsgálatok is alátámasztják. ${ }^{19} \mathrm{~A}$ banki kölcsönzés dinamikája lassult, volumene is csökkent a kis- és középvállalkozások esetében, a bankok klasszikus pénzügyi közvetítői szerepének megroggyanása ebből a szempontból is megmutatkozik. ${ }^{20}$

3. A gazellák arányát mindenféleképpen növelni igyekvő gazdaságpolitika egy sokszor mellőzött, ám valóban nehezen mérhető választással (trade-off) szembesül. Az információs forradalom óta kibontakozó digitális gazdaság korában a hálózati hatás révén domináns szerephez jutó nagyok által nyújtott termékek és szolgáltatások egyre inkább olyanok, hogy a marginális költség szinte nullára csökkent (például szoftverek, applikációk). Így ez a monopolisztikus jellemző valójában nagyobb diffúziót, szélesebb spektrumú életminőségi javulást is képes eredményezni. Valójában tehát a makrofundamentumok által eddig statisztikailag nem kellően megragadott minőségi növekedés jelenségét látjuk egyre több területen. Ezért átváltás jön létre két szakpolitikai törekvés között: a gazellák arányát a nagyok rovására növelni igyekvő, illetve a minőségi értékteremtést támogatni igyekvő között.

Úgy tűnik tehát, hogy egy bizonyos fokú koncentrációt el kell fogadnunk. Összességében arra van szükség, hogy a 2008-2009-es válság után megnövekedett állami

\footnotetext{
${ }^{18}$ Természetesen a mintázat országról országra eltérő, a strukturálisan nagyon lemaradt mediterrán országokban az ilyen típusú tőkeallokáció-változás nagyobb volumenű, míg az uniós magországokban nem mutatható ki hasonló nagyságrend. Kiválóan mutat erre rá Gopinath és szerzőtársai [2017].

${ }^{19}$ Bár a fiatal startupok a kis- és középvállalkozások csoportján belül fontosak, az összfoglalkoztatásnak csak a 17 százalékát adják, és csak töredékük járul hozzá jelentősen a munkahelyek létrehozásához. A startupok piacra lépési rátája is folyamatosan csökkent az OECD-országok többségében. Például az Egyesült Királyságban 2001-2004 között még átlagosan 14,6 százalékos volt ez a ráta, 2009-2013 között viszont már csak 9,9 százalékos; az Egyesült Államok ugyanezen időszakokra vonatkozó adatai: 9,9, illetve 7,7 százalék, a magyarországi adat 11,1 és 7,5 százalék (OECD DynEmp Projekt - https:// www.oecd.org/sti/dynemp.htm).

${ }^{20}$ Sőt az alacsony kamatok politikája szintén a nagyobb vállalatok számára történő hitelezést/kölcsönnyújtást támogatja. 2008-ban a bankok 15 százalékkal több kamatot fizettettek a kis- és középvállalkozásokkal a nagyvállalatokra kivetettekhez képest, 2015-ben már 56 százalékkal többet (OECD [2017b]). Az ezzel kapcsolatos elégedetlenség és bizalmatlanság teret nyert. Brown-Lee [2017] ezt dokumentálja az új gazellák esetében az Egyesült Királyságban.
} 
szerepvállalást a finanszírozás terén mérsékeljük. Impulzusos jellegü beavatkozásra lehet szükség a zombikultúra megtörése és a gazellák számára oly fontos alternatív külső piaci finanszírozási lehetőségek bővítése érdekében.

\section{A pénzügyi szféra és a reálgazdaság megbomlott harmóniája}

A pénzügyi szféra és a reálgazdaság közötti harmónia megbomlott, ezt a 2008as válság is jelezte. Nagy lett a távolság a két világ között. Az Egyesült Államokban a forgalmazott értékpapírok összértéke a GDP 300 százalékát is meghaladta a Lehman Brothers csődje előtt, később megindult a konszolidáció időszaka, de még így is 200 százalék felé tendál. De tetten érhető ez a túlzott mértékü hitelfogyasztás jelenségében (excessive credit consumerism), abban, hogy a belsö pénzügyi kitettség a derivatív piacokon túlzott méreteket öltött (ESRB [2016]). Mindez jelzi, hogy a pénzügyi szféra a reálgazdaságon túlterjeszkedett, ma már nem elsősorban pénzügyi közvetítő, vagyis a reálszektor termelékenységét előmozdító csatorna, hanem önmagából élő pénzügyi „kaszinóvá” vált. A szabályozó persze igyekszik élénkíteni (alacsony reálkamatok), a likviditás azonban olyan eszközök felé megy, amelyek piacán ma már a buborék szó használata teljesen adekvát (például 2012-től 2019 szeptemberéig lényegében nagyfokú drágulás volt tapasztalható az ingatlanpiacon, az UBS [2019] több euróövezeti nagyváros kapcsán mutatott ki buborékot).

A pénzügyi szféra olyan hihetetlenül komplex és integrált globális rendszer lett, hogy a visszásságait csak globálisan lehetne eredményesen megoldani, ugyanakkor a reálgazdaságon is túlterjeszkedő természetét más visszásságok teremtik és tartják fenn (szabályozatlanság, vállalatok közti egyenlötlenségek miatti nagyvállalati dominancia, amelynek haszonélvezői a pénzügyi szféra jelenlegi természetének fennmaradásában érdekeltek). Ez egyúttal azt jelenti, hogy már túlhaladtunk az úgynevezett visszatérési ponton (point of no return), amely elött a folyamatok egymásba fonódó konfigurációját még lehetett volna befolyásolni, netán vissza lehetett volna fordítani bizonyos káros folyamatokat. Természetesen a globális pénzügyi rendszer számos helyen töredezett, ami eltérö mintázatokat s elméletileg kivitelezhető szabályozási lehetőséget jelent.

$\mathrm{Az}$ általunk is említett demográfiai problémák visszacsatolnak a folyamathoz, hiszen az aktív munkaképes korú népesség csökkenése és az idősödés folyamata növelte (és még növeli) a megtakarítási hajlandóságot, azon keresztül mérsékelte (és még tartósan mérsékelni is fogja) a reálkamatokat, ilyesformán pedig a pénzügyi rendszert, konkrétan pedig a bankrendszert elkezdhette uralni a pénzügyi befektetési célú tevékenység (nem pedig a reálgazdasági folyamatok támogatása hatékony közvetítésen keresztül, ezért sem meglepö, hogy a kis- és középvállalkozási szektornak nyújtott banki kölcsönök/hitelek aránya csökken).

Európában elsősorban az adósságfinanszírozó hitelkonstrukciók dominálnak, a gazelláknak viszont növekedési tőkére van szükségük (már csak ezért sem lehet megállni az európai bankunió létrehozásánál, európai tőkepiaci unióra is szükség 
van). Az Európai Befektetési Bank felmérései ${ }^{21}$ szerint az új norma az lett, hogy a bankok nem hiteleznek eleget a kis- és középvállalkozásoknak (főleg nem a gazelláknak vagy az azzá válni igyekvő kockázatosabb vállalkozásoknak); egy másik vélekedés szerint viszont pont eddig lehetett túlzott hitelezési gyakorlatot tapasztalni, most viszont megromlott a bizalom infrastruktúrája, és a biztonságosabb, alacsonyabb kockázatú ügyfelek és lehetőségek felé fordulnak a bankok (például nagyvállalatok, pénzügyi befektetések felé). ${ }^{22} \mathrm{Az}$ interpretációk tehát sokszor többértelműek. Az biztos, hogy történelmileg is rekordalacsony szintre süllyedtek a reál- és a nominális kamatok (például az Európai Központi Bank esetében az egynapos betéti kamatok 2014 második felétől gyakorlatilag negatívak), amivel párhuzamosan viszont a reálgazdasági termelékenységi növekedési adatok nemhogy javulnának, de immár több évtizede mutatnak romlást, ahogy már bemutattuk. ${ }^{23}$

A folyamatokat az is befolyásolta, hogy az adórendszerek progresszivitása vesztett erejéből: a munkát terhelő adók növekedtek, míg a tőkét terhelök csökkentek. Ennek hátterében az a gazdaságpolitikai cél lebegett, hogy stimulálják a növekedést, a tökebefektetéseket; a folyamatok tartalma és alakja persze másképp alakult: a pénzügyi szektor növekedéséhez, a reálgazdasági teljesítmény mérséklődéséhez, az egyenlőtlenségek meglódulásához vezetett. ${ }^{24}$ Ezért is valószínű, hogy az OECDországokban az adórendszer gazellastimuláló ereje mára jelentősen meggyengült. ${ }^{25}$ Ez az egy szempont is komplex elemzéseket kíván, mert a gazellák aránybeli csökkenésének magyarázatakor érdemes bekapcsolni a cégalapítást követő szabályozói környezet profitabilitást befolyásoló erejét is.

Továbbá a kialakult diszharmónia rendszerében van egy hajlam (bias) a nagyvállalatok felé fordulásra, ami roncsolja a piacok megtámadhatóságát, hisz a nagyok szabadalmaikat stratégiailag használva, jelentősen megnehezít(het)ik az új szereplők, így a gazellák belépését és fejlődését. Az új „normálállapot” ma már a pénzügyi befektetések túlsúlya a reálgazdasági invesztíciók rovására, amelyek egyébként

${ }^{21}$ https://www.eib.org/attachments/mooc-regions-cities-sme-factsheet-en.pdf.

${ }^{22} 2017$ után egyre több bank kezdett el „puha” információkat is gyüjteni a vállalatokról (Ferri és szerzőtársai [2019]), hogy hitelképességüket felmérje. Ez javította a hitelezés/kölcsönnyújtás intenzitását.

${ }^{23}$ Az eredeti szándék az élénkítés lenne, ám torz hatás alakult ki: tudjuk, hogy a piacok nem tisztulnak meg maguktól, a tisztuláshoz az állam értő beavatkozására van szükség. A helyzet viszont úgy fest, hogy a beavatkozás csak elodázza a megtisztulást, gyakorlatilag lélegeztetőgépen tartják a zombikat, így azután aligha lehet meglepő, hogy a valódi innováció és így a termelékenységi növekedés elmarad. Másképpen: szinte teljesen leszükült a beavatkozási mozgástér, nem véletlenül hangsúlyozta az Európai Központi Bank új elnök asszonya, Christine Lagarde 2019 szeptemberében, hogy a monetáris politika csak az egyik lehetőség (utalva a monetáris politika tehetetlen szerepére az élénkítés és a recesszió elkerülése kapcsán).

${ }^{24} \mathrm{Az}$ EU-országok adóbevételének több mint felét a munkát terhelő adók adják, nagy a tér a csökkentésre (Kalyva és szerzőtársai [2018]).

${ }^{25}$ Henrekson-Johansson [2008] szerint a munkát terhelő nagyobb adók egyfelöl ösztönzik az önfoglalkoztatást, másfelöl viszont gátjai is a nagyobb növekedésnek/bővülésnek. Az adórendszerek progresszivitásának kérdése napirenden van, ugyanakkor komolyabban fel kell lépni az adóelkerülés és az adócsalás ellen, hisz a jelenlegi szisztémában a nagyvállalatok, a magas jövedelműek nagyobb kapacitással is rendelkeznek ahhoz, hogy drága adótervezési tanácsokat vegyenek igénybe adócsökkentés érdekében, illetve hogy kevesebb realizált jövedelmet tüntethessenek fel (Brys és szerzötársai [2016]). 
kockázatosabb technológiai vagy nem technológiai innovációkat és kutatást-fejlesztést takarnának. ${ }^{26}$ Számos további indikátor historikus fejlődése támasztja ma már alá ezt az állítást (például részvény-visszavásárlások intenzívebbé válása, túlzott mértékü hitelfogyasztás, a munkajövedelmek arányának csökkenése, míg a tőkejövedelmek részaránya növekszik, stb.). Már szóltunk a kialakult rendszer lényegi vonásáról: a nagyvállalatok dominanciájáról, amelynek révén akadályokat görgetnek a belépni kívánó startupok elé. ${ }^{27}$ Mindez rendszerszinten ágyaz meg a bérstagnálásnak, a gyengülő növekedési dinamika munkahely-megtakarító jellegének, a mérsékelt innovációs aktivitásnak, valamint a növekvő egyenlőtlenségeknek, végső soron megalapozza a gazellák hanyatlását. ${ }^{28}$

Egyáltalán nem irreleváns tehát, hogy mivel az ipar 4.0 (és a digitális gazdaság) jelentős $\mathrm{K}+\mathrm{F}+\mathrm{I}$-vel összefüggő reálgazdasági beruházásokat igényel - amelyeket a fiatal, sok esetben kisvállalatok (így a gazellatulajdonságúak) nagyon nehezen engedhetnek meg maguknak-, az ismertetett jelenség fokozódása reális forgatókönyv.

\section{Az ipar 4.0 bizonytalanságai}

Természetesnek tűnik, hogy a gazdasági kormányzás próbálja segíteni gazellák létrejöttét annak érdekében, hogy azok mind sikeresebben bekapcsolódjanak a jelenleg zajló negyedik ipari forradalomba és a digitális átalakulásba, hogy a termelékenységi hatás is érvényesülhessen. ${ }^{29}$

Tágabb megközelítés szerint az ipar 4.0 és a digitális gazdaság nem más, mint 1 . az információs-kommunikációs technológia alkalmazása az információk digitalizálására és a különböző rendszerek (termelői és fogyasztói/felhasználói oldalon) integrálása a vállalatokon belül és a vállalatok között; 2 . szenzorok széles körü alkalmazása a virtuális és a fizikai rendszerek hatékonyabb ellenőrzésére és felügyeletére, robotika, illetve additív gyártás (3D nyomtatás) alkalmazása; 3. digitalizált, internetalapú folyamatos kommunikáció és interakció nemcsak emberek vagy emberek és gépek között, hanem gép-gép kapcsolatban is; 4. szimuláció és (virtuális) modellezés a termelési folyamatok és a dizájn során; 5. felhőalapú szolgáltatások használata, kiterjesztett

${ }^{26} \mathrm{Az}$ EU bankjainak árnyékbanki kitettsége igen jelentős (ESRB [2017] 35. o.). Beszédes a részvényvisszavásárlás növekvő trendje is, amivel mesterségesen kívánják lendületbe hozni a részvénypiacot, jelezvén, hogy nem feltétlenül keresnek (nem találnak) kockázatosabb, de a termelékenységet javító reálgazdasági befektetéseket (1990-ben az S\&P 500 tőzsdei cégek alig 40 százaléka vásárolt vissza részvényeket, arányuk 1997-2003 között 60 százalék volt, manapság pedig már 85 százalék (Ro [2014]).

${ }^{27}$ A nagyobb vállalatok jobban képesek vertikális korlátozásokat kialakítani és szabadalmaikat úgy felhasználni, hogy csökkentsék az igen költséges $\mathrm{K}+\mathrm{F}+\mathrm{I}$-tevékenységek kockázatát (Sovinsky és szerzőtársai [2016]).

${ }^{28}$ Hall és szerzötársai [2017] érzékletesen bemutatja, hogyan képesek a nagyok a szabadalmaikkal az átfedő technológiákkal próbálkozó újak piacra lépését ellehetetleníteni.

${ }^{29}$ Kovács [2015] bemutatta, hogy a finn gazdasági kormányzás a költségvetési politikáján keresztül sikeresen terelte gazdaságát az információs és tudásalapú gazdaság felé. Megjegyezzük, hogy erre ott a kilencvenes évek elején került sor, azóta a fejlett világban jelentősen beszűkültek a költségvetési források, a világ komplexebb, mint annak elötte, ezért félő, hogy a beavatkozás hatékonysága ma korántsem lenne akkora. 
valóság (augmented reality) és adatbányászat, adattudósok alkalmazása a Big Data kiaknázására gépi tanulás és mesterséges intelligencia bevetésével.

Az ipar 4.0 szempontjából releváns iparágakban tevékenykedő - potenciális vagy már jelenleg is annak számító - gazellák támogatása azért is tünik fontosnak, mert könnyen lehet, hogy rajtuk múlhat az ipar 4.0 technológiai és nem technológiai megoldásainak elterjedése és transzformatív ereje. Az empíria ugyanis azt sugallja, hogy a gazellák serkentik a felívelő és erősödő iparági növekedést, nem pedig az eleve magasabb iparági növekedés hívja életre az adott szektorban a gazellákat. ${ }^{30}$

Mégis rendkívül nagy a bizonytalanság a tekintetben, hogy valóban képes lehet-e a szakpolitika az ipar 4.0 és a digitális gazdaság ,jelzőfényénél” okos gazellapolitikát végrehajtani. A bizonytalanságokat bizonyos átváltások és nem szándékolt következmények halmazai adják.

Az IPAR 4.0 ÉS A DIGITÁLIS GAZDASÁG BIZONYTALANSÁGAIRÓL

Átváltások

- A gyors diffúzió és a bizalmi szint közötti átváltás: az átformáló technológia (disruptive technology) ellenérdekeltjeinek tábora népes, a status quo viszont a bizalmat erősíti.

- A kiberbiztonság fokozása és az energiafogyasztás közötti átváltás: a kiberbiztonság fokozása az egyes eszközök nagyobb energiahasználatát válthatja ki.

- A munkaerőpiac rugalmasabbá tétele és az innovációs teljesítmény fokozása közti átváltás: elméleti közgazdászok szerint a rugalmasabb munkaerőpiac előmozdítja az általános innovációs teljesítményt (olcsóbb felvenni kreatívabb és innovatív munkavállalót, $\mathrm{s}$ olcsóbb elbocsátani a kockázatkerülőbbeket), viszont az Egyesült Államok évtizedes példája megmutatta - ahol a világ egyik legrugalmasabb munkaerőpiacával találkozhatunk -, hogy a vállalatok inkább vesznek fel olcsó (nem annyira képzett és nem oly innovatív) munkaerőt, mintsem hogy befektetnének (emberi) tőkébe. ${ }^{31}$ A rugalmasabb munkaeröpiac Európában a bérnövekedés visszaesésével, bérstagnálással is járhat, ami ellenösztönzője az innovációnak. Ez pedig a gazellává válás szempontjából káros.

- A Big Data alkalmazása és az adatbiztonság fokozása közötti átváltás, illetve a Big Data és a valós idejü foglalkoztatotti monitoring és a termelékenység javulása közti átváltás. A Big Datához való nyilvános hozzáférés közben nehezen érvényesíthető az adatvédelem és -szabályozás. A digitalizáció Big Datát eredményez, arra építő alkalmazásokat szül (például a dolgozók viselkedéséről nyert adatok elemzése - People Analytics), amelyek intenzív használata negatívan érintheti a dolgozók mentális állapotát, termelékenységüket, ami szintén akadályozza a gazellává válást. A gazellák erejét az emberi tőke jobb kiaknázási szintje adja (Sage [2017] rámutat, hogy a gazellák jellemzően jobban építenek automatizált HR-tevékenységre, a munkavállalókkal kapcsolatos adatok elemzésére bizonyos

\footnotetext{
${ }^{30}$ Ezt számos ország gazellakutatása kimutatta (Hollandia esetén lásd Bos-Stam [2013]). Az ipar 4.0 kapcsán azonban hangsúlyozzuk a képzettségbeli követelmények növekedésének (upskilling) a fontosságát, hogy a standardizálás és robotizálás (automatizálás) időszakában megszűnő munkahelyeket máshol értelmes munkahelyekkel lehessen felváltani.

Egyelőre még a nagyvállalatok felkészültebbek az ipar 4.0 technológiáinak alkalmazására, esetükben például 2014-ről 2016-ra a felhőalapú szolgáltatást használók aránya 35 százalékról 44-45 százalékra nőtt, míg a kis- és középvállalkozások hasonló aránya 17-18 százalékról csak körülbelül 19 százalékra (https://ec.europa.eu/eurostat/statistics-explained/index.php/Cloud_computing_-_statistics_ on_the_use_by_enterprises\#Enterprises_using_cloud_computing).

${ }^{31}$ Legújabb könyvében erre is rámutat Skidelsky [2018] (305. o.).
} 
döntések meghozatalában, és törekednek minél több valós idejű adat beszerzésére és kiértékelésére.) Az ipar 4.0 és a digitalizáció korában tartósabb növekedés eléréséhez segítheti őket hozzá a People Analytics eljárások alkalmazása (HR, tudásmenedzsment stb.).

Nem szándékolt következmények

- A digitalizált összekapcsoltság miatt megnőhet az ipari kémkedés, fokozódik kiberterrorizmus: ha a szereplőket félelemmel tölti el a tudat, hogy a kiberbiztonság kérdése még sokáig megoldatlan marad, akkor inkább lassulni, mintsem gyorsulni fog az ipar 4.0 diffúziója. (Az Oxford Economics [2019] egyértelműen azt mutatja, hogy nő azon kis- és középvállalkozások aránya [a 2018. évi 7 százalékról 27 százalékra nőtt], amelyek komolyan tartanak a kiberkockázattól.) ${ }^{32}$

- Az állam támogató szerepe visszájára sülhet el, az állami támogatások túlfogyasztása buborékokat szülhet, ami eredménytelenséget, a zombik életben tartását jelenti.

- A gyors növekedésű vállalat és a gazella tipikusan magasabban képzett emberi tőkével gazdálkodik, az automatizálás, a rugalmasabb munkaerőpiac lehetősége már az ő munkahelyeiket is veszélyezteti, és ha a gazdaság nem tudja őket másutt felszívni, akkor erősödik az aggódásérzés, gyengül a bizalom, az állam fenntarthatósága, a politikai stabilitás. Összességében a gazellák egyre rövidebb életüek lesznek, és megszűnik inkluzív növekedést támogató jellegük.

\section{Az ökoszisztéma jellemzői}

A közpolitikának ma már egy sokkal komplexebb világgazdaságban kell(ene) formálódnia. A hatékony gazdasági kormányozhatóság egyre több korlátba ütközik: a szekuláris stagnálás minden kormányzati igyekezet ellenére alakult ki. Az inkluzív gazdasági növekedést támogató gazellák ösztönzését célzó közpolitika állandóan változó komplex kihívásokkal néz szembe, a beavatkozás megkonstruálása közben pedig figyelembe kell venni, hogy a társadalmi-gazdasági innovációs ökoszisztémát egyre inkább jellemzi a volatilitás, a komplexitás, a bizonytalanság és a többértelmüség (volatility, complexity, uncertainty, ambiguity, VUCA) (Bennis-Nanus [1985]). A következőkben a gazellák vizsgálatán keresztül e tényezőkre térünk ki röviden.

\section{Volatilitás}

A komplexitás növekedésével párhuzamosan nemcsak a makroszféra, hanem a mikroszféra volatilitása is fokozódik. Makroszinten a kihívások nemlineáris természetűek, és ezért nagyobb a váratlan események valószínüsége a társadalmi-gazdasági

${ }^{32}$ Az Egyesült Államokban pályázati úton támogatják a termelő cégeket, hogy minél előbb szerezzenek be okos szenzorokat és automata kontrollrendszereket az energiahatékonyság növelése érdekében (https://www.energy.gov/articles/doe-announces-70-million-cybersecurity-institute-energyefficient-manufacturing). A gond ezen eszközök kiberbiztonsági kockázatával van, ami miatt a cégek nem az elképzelt intenzitással jelentkeznek a pályázatra. Ha most megfontoljuk, hogy több millió európai polgár személyes és metaadata csupán néhány amerikai óriás kezében van, akkor nem lehetünk túl optimisták a hasonló programok sikerét illetően Európa kapcsán sem. 
innovációs ökoszisztémában [például a pénzügyi rendszerben a nagysebességű számítógépeken futtatott algoritmusokon alapuló automatizált kereskedés (highfrequency trading) nagyobb volatilitást visz a rendszerbe, következésképpen tetemesebb és gyorsabb összeomlást idézhet elö]. ${ }^{33}$

Míg a makroszintű alacsony volatilitás a kódolódó instabilitások időszaka (magasabb lesz a kockázatvállalási hajlandóság, ezáltal a háztartások/gazdaságok magasabb adóssággal mennek bele egy válságba, ezzel még mélyebb megrázkódtatásnak téve ki magukat), addig a gazellák siker- és definíciós kritériuma a tartós, kimagasló, alacsony volatilitású növekedés. A valóságban azonban a gazellák volatilisek, a gyorsabb ütemü növekedést egy renyhébb időszak követi, ezért az impulzusos jellegü támogatásuk csak fokozná a volatilitást (az impulzusos iparpolitika csak azt érné el, hogy az optimumnál nagyobb lenne a gyors növekedésü szakasz, a visszaesés pedig még mélyebb lenne), a folytonos támogatás viszont a túl fontos, hogy elbukjon (too important to fail) elv ${ }^{34}$ gyakorlati megvalósulása lenne, és ezen keresztül kiiktatná a szelektálódás evolúciós folyamatát, és nagy valószínüséggel erkölcsi kockázatot építene be a rendszerbe (zombik jönnének létre).

\section{Komplexitás}

Az információs forradalom nagyban segítette a globalizáció komplex kialakulását. Napjainkat a sokféleség, az egyidejüség, az intenzív hálózatosodás koraként írhatjuk le, amelyet aszimmetrikus interdependenciák, a mellékhatások globalizálódása, nemlineáris változások, irreverzibilitások, a makroszférát elérő mikroszintű ingadozások, valamint kumulatív okság jellemez (a pénzügyi szféra és a reálgazdaság, valamint a klímaváltozás és az államok költségvetés-politikai mozgástere közötti összekapcsolódás). Ebből legalább két dolog következik.

1. Vitathatatlan, hogy az újfajta iparpolitikának a rendszert a maga teljességében kellene tekintenie (globális szemlélet), ami jelenlegi tudásunk szerint lehetetlen. Csak két példát említünk. Az első: a globális és liberalizált pénzügyi piacok szabályozása csak és kizárólag globálisan képzelhető el. Erre gyakorlatilag semmilyen hajlandóság nem mutatkozik a folyamatot érdemben befolyásoló felső körökben (például 2008 óta még mindig nem megoldott a „túl nagy, hogy elbukjon” jelenség, a nagyok még nagyobbak lettek, nőtt a koncentráció, $s$ a nem banki pénzügyi közvetítés felfutása növeli a rendszerkockázatot - Admati [2019]). A másik kérdés az inkluzivitás, amelyet az újfajta iparpolitikának szintén szem előtt kell tartania, viszont mivel a gazellák növekedési gócpontokban koncentrálódnak, bármiféle rájuk irányuló (horizontális vagy vertikális) iparpolitikai figyelem csak tovább erősítené a más régiók kiürülésének tendenciáját, és ezáltal fokozná a regionális egyenlőtlenségeket. ${ }^{35}$

\footnotetext{
${ }^{33}$ Lásd például a 2010. május 6-i flash crasht (https://en.wikipedia.org/wiki/2010_Flash_Crash).

${ }^{34}$ A gazdasági kormányzás számára túl fontos alapelvek miatt: a termelékenység mielőbbi javítása, az inkluzív növekedés érzékelhető beindítása.

${ }^{35}$ Aligha lehet véletlen, hogy nő azon intézkedések száma, amelyek révén külföldről akarnak bevonzani gazellákat (https://ec.europa.eu/growth/tools-databases/regional-innovation-monitor/support-
} 
2. Fontosabbá vált a hálózati hatás, és ezért érdemesebb a gazellák támogatása során hálózatos beágyazottsággal is rendelkező inkubátorokkal próbálkozni. Mindebből következik, hogy érdemes azt a komplex kölcsönhatást is figyelembe venni, hogy miképp is hat a gazellatámogató politika a regionális különbségekre. Tulajdonképpen inkább nem is gazellákra, hanem nagy hatású vállalatokra (high-impact SMEs) van szükség, amelyek több régióban próbálkoznak, és a kiegyenlítettebb növekedést és inkluzivitást szolgálják. Ez azonban inkább az egész társadalmi-gazdasági innovációs ökoszisztéma teljesítményén múlik, mintsem egy-egy koncentrált, időben korlátozott és izolált szakpolitikán.

\section{Bizonytalanság}

A komplexitás és a volatilitás miatt nincs egyetlen felelőse a dolgoknak, nincs semmilyen szervezet vagy egyén, amely/aki precízen, tudományosan megalapozottan át tudná látni ex ante az egész rendszert, valamint képtelen az egyes gazdaságpolitikai/szabályozásbeli intézkedések hatásainak teljes vertikumát előre feltárni. Még a bőséges információkkal és adatokkal jellemezhető digitális gazdaság korában is inkább csak hiszterézissel tudjuk, hogy nagyjában-egészében mi folyik a gazdaságban. ${ }^{36}$ Nincsenek tehát üzembiztos ismereteink a valós és pillanatnyi állapotról, nincsenek ezért végső megoldásaink a vázolt kihívásokra sem. Ebből legalább három dolog következik.

1. Nem feltétlenül igaz az, hogy a piaci szereplők mindig jobb információval rendelkeznek, mint az állam, ezért az állami beavatkozásnak, ha úgy tetszik, missziók (például ökohatékony zöldgazdaság kiépítésének piacösztönző mechanizmusát kellene az államnak inkább támogatnia, mintsem a misszióban szerepet vállalni kész gazellákat) kijelölésének és koordinálásának lehet terepe az ipar 4.0 kibontakozásában, a digitális technológiai-gazdasági paradigma megalapozásában, ha az állam fenntarthatóságiinformátor-szerepét sikerül erősíteni. ${ }^{37}$

measure/vienna-start-package-2018). Ennek sikerében talán kételkedhetünk, hiszen már a külföldi közvetlen tökebefektetések esetén is tapasztalati tény, hogy inkább növelték, mintsem csökkentették a helyi ökoszisztéma sérülékenységét (lásd Sass [2019]).

${ }^{36}$ Mivel a kormányzat csak az inputok fölött tud kontrollt gyakorolni, azaz a rövid és hosszabb távú kimenetek (outcomes) teljes ismerete nem áll rendelkezésre, ezért nem meglepő, hogy a gazellastimuláló kormányzati programok hatásait nem sikerül pontosan számszerűsíteni. Az ipar 4.0 és a digitális transzformáció felgyorsításában betöltött szerepük is rendkívül bizonytalan.

${ }^{37}$ Nem osztjuk a már többször idézett Mazzucato azon álláspontját, hogy a sikeres beruházásokból származó profitok társadalmasításához az államnak jobban kellene beavatkoznia, hiszen a kudarcok költségét is mindenkor az adófizetők viselik. Meglátásunk szerint ez totálisan kioltaná az innovációs dinamizmus egyik meghatározó hajtóerejét, a Kornai [2010] által kiválóan leírt nagy jutalmat. Az állam fenntarthatóságiinformátor-szerepe erősíthető a cégek közzétételi kötelezettségeinek módosításával, amelyben a környezeti és társadalmi kérdések iránti fogékonyságukat, a fenntarthatóság melletti elkötelezettségüket is közvetíthetik a fogyasztók, a részvényesek felé. Ennek, mármint az információ nyújtása utáni piaci fegyelmező erő létének empirikus igazolásához lásd Gantchev és szerzőtársai [2019]. 
2. A bizonytalanság miatt a pénzügyi szektor érdekelt a stabilabb, alacsonyabb kockázatú vállalatok (nagyok) preferálásában, ami a gazellává válást megnehezíti (a hitelképességi vizsgálatok ráadásul mennyiségi jellemzőkre vonatkoznak). ${ }^{38}$

3. Az is következik, hogy nincs mód a gazellák előzetes kiválasztására, tökéletlen kijelölésük csak elnyújtaná a zombik agóniáját, és a rendszerbe kontraszelekciót is építene; ezért lehet indokolt, hogy a szakpolitika inkább tegye olyanná a társadalmigazdasági innovációs ökoszisztémát, hogy a kísérletezgetésre (a bukások elviselésére) alkalmas közeg jöjjön létre (a túlszabályozás, ${ }^{39}$ a túlzott adminisztrációs terhek csökkentésével, a pénzügyi szektorbeli verseny fokozásával stb.).

\section{Többértelmüség}

A fundamentális bizonytalanságokat ismeretlen ismeretlenek (unknown unknowns) szövik át, amelyeknek közpolitikai jelentőségük van. Ebből kifolyólag sokszor csak homályos, többértelmü interpretációk és/vagy forgatókönyvek fölvázolására van mód. Csak négy példát említünk.

1. A vállalatok közötti egyenlötlenség egyszerre implikálja azt, hogy egyrészt azt kellene ösztönözni, hogy csökkenjen a nagyvállalati dominancia, másrészt ez a dominancia adott esetben forrása és terepe is lehet az önfoglalkoztató és kreatív emberek üzleti tevékenységének, akik később gazellákat alapíthatnak.

2. A piacok nem megtisztuló természetének felismerése miatt beavatkozó állam és a független jegybank feladata a fellendülés előmozdítása, másfelől az erre irányuló beavatkozás (az olcsó pénz politikája, negatív kamatok stb.) lassítja le az egyébként is nagyon súrlódásos megtisztulási folyamatot (zombicégeket tart életben, ingatlanpiaci buborékoknak ágyaz meg, konzerválja az alacsony és romló dinamikájú termelékenységet és a kirekesztő jellegü gyenge növekedést, a nagyvállalati szféra dominanciáját és érdekeltségét a pénzügyi szektor kiteljesedésében a reálgazdaság kárára).

3. Amikor a közvetlen támogatásokon alapuló iparpolitika tervezői és kivitelezői azt tapasztalják, hogy néhány gazellánál lassul a növekedés, akkor az lehet természetes volatilitás, de azt is jelentheti, hogy a támogatások nem segítik a szervezetek tanulási képességét, azok piaci körülmények között elbuknának. ${ }^{40}$

4. A negyedik példa a többértelmüségre az, hogy az ipar 4.0 és a digitális gazdaság innovációira is igaz lesz az exaptáció lehetősége, azaz hogy a cégek nem pusztán átvesznek és a helyi viszonyokhoz igazítanak egy-egy innovációt úgy, hogy lényegében ugyanarra a célra használják, mint amire az adott innovációt szánták, hanem továbbfejlesztik, és teljesen más területen, teljesen más célra használják. Az ipar 4.0 és

\footnotetext{
${ }^{38}$ Minél fejlettebb a pénzügyi piac, annál kisebb az esély a gyors növekedés fenntarthatóságára. Arellano és szerzőtársai [2012] és Sorin [2019] igazolja ezt több oldalról.

${ }^{39}$ Kimutatott például, hogy a környezetvédelmi szabályozás, az ezzel kapcsolatos szakpolitika szigorúsága igenis befolyásolja a gazellává válást (lásd Colombelli és szerzötársai [2019] munkáját a környezeti hatások csillapításának céljával fogant, úgynevezett ökoinnovátor gazellák kapcsán).

${ }^{40}$ A skóciai High-Growth Spinout és a német High-tech Grunderfounds programok tapasztalatai ezt erősítik (OECD [2013]).
} 
a digitális technológiai innovációk is ilyen többes értelemmel bírnak, ugyanakkor ez elözetesen aligha tudható. Következésképp meglehetősen korlátozott fantáziára vallana a gazellák az irányú állami támogatása, hogy konkrét ipar 4.0- és digitális technológiákat konkrét és ismert célokra használjanak.

\section{Zárógondolatok}

Kétrészes tanulmányunkban abból indultunk ki, hogy a világgazdasági problémák árnyékában a gazdasági kormányzásnak eredményeket kell produkálnia több fronton, így a romló termelékenységi dinamika és az inkluzív növekedés érzékelhetőbb beindítása terén is. Ekkor pedig az úgynevezett gyors növekedésű vállalatokra való koncentrálás az ipar 4.0 és a digitális gazdaság kialakulásának korában szinte magától adódik. Tanulmányunkban a gazellák természetét a komplex világgazdaságban igyekeztünk felfejteni. Elemzésünk alapján a következö hat megállapítást tehetjük (főleg az EU gazdaságára vonatkoztatva): 1. magas fokú heterogenitás jellemzi őket; 2. oroszlánrészük a szolgáltatási szektorban koncentrálódik; 3. az ipar területén rövidebb életüek, növekedésük hamarabb lelassul, mint a szolgáltatási szektorban; 4. az innovatív gazellák növekedése nem egyenletes (például gyorsabb növekedési időszakot látványosabb lassulás követ); 5. növekedési potenciáljuk sokszor a cégalapítás előtti tényezőkön múlik (vállalkozói attitüd, menedzsmentszemlélet, az elképzelt üzleti modell megvalósítása közbeni tanulási képesség stb.), időről időre növekedési fordulatokkal találkoznak, azaz fejlődésük és növekedésük meglehetősen összetett; 6. a tartósabb trend a gazellák arányának és foglalkoztatásbővítő képességének gyengüléséről árulkodik. Mindezek miatt az a benyomás erősödik, hogy az európai innovációs ökoszisztéma gazellatámogató ereje gyengülöben van.

A legfrissebb nemzetközi irodalom és az EU-ra koncentráló szakpolitikai relevanciájú munkák egy újfajta iparpolitika szükségszerü eljöveteléről szólnak, mert az ipar 4.0-tól és a digitális forradalomtól a termelékenység és az életszínvonal látványos javulását remélik. Mintha a beavatkozó államnak lenne a feladata, hogy ne csupán a piackudarcok megoldásán, de új piacok teremtésén és a meglévők formálásán is dolgozzon, ${ }^{41}$ e tekintetben bizonyos iparágakban a gazellák szerepe releváns lehet.

Kutatási kérdésünkre válaszunk az, hogy bár teljesen jogos az a társadalmi elvárás, hogy a modern gazdasági kormányzás igazolható és hathatós eredményeket produkáljon, ennek viszont biztosan nem az a módja, hogy fölhagy a semlegesség elvével, és a gazellákra koncentrálva újfajta iparpolitikai megközelítéssel igyekszik élni a termelékenységi javulás és az inkluzívabb növekedés szorgalmazása érdekében az ipar 4.0 és a digitális gazdaság korában. Figyelembe véve a gazellák természetét, a kölcsönhatások dinamikus konfigurációjának jellemvonásait (VUCA), azt állítjuk tehát, hogy egy tértől és időtől függetlenül alkalmazható, újfajta iparpolitika pusztán önáltatás volna, megkísértése felérne egy naiv (Laplace) démonidézéssel.

\footnotetext{
${ }^{41}$ Ennek a hangsúlyozásával foglalkozó munkája szerzett lényegében hírnevet Mariana Mazzucatónak, aki számos díjat kapott eredeti és kritikus gondolataiért (Mazzucato [2013]).
} 
Sőt minden olyan munka, amely az iparpolitika primátusát húzza alá, továbbá azzal érvel, hogy a múlt adataira építve az állam képes a változások irányát előre látni és ekképpen irányba állítani az innovációs ökoszisztémát, téves feltételezéseken és a valóság komplexitásának teljes negligálásán nyugszik. ${ }^{42}$

A gazellák sem a semmiből érkeznek, azaz a szakpolitikának inkább a környezettel, az innovációs ökoszisztéma strukturális váltási képességének ápolásával érdemes foglalkoznia az ipar 4.0 és a digitális transzformáció korában. Ez gyakorlatilag a gazdasági kormányzás bizalomépítő csatornája, és alapvetően a következő két alapelvre kellene épülnie. Egyrészt a jó állam alapértékeinek pallérozására, az együttműködő és értékelvü gazdasági kormányzás kultúrájának megteremtésére (például átláthatóság, hitelesség, elszámoltathatóság, intézményi fékek és ellensúlyok rendszere, decentralizált és az együttmüködést tovább mélyítő, a demonstrációs szerepet felvállaló és az inkluzivitás és az egyenlő lehetőségek biztosításának szellemiségében tevékenykedő közszféra stb.). Másrészt a tudásteremtés szempontjából teljességre törekvő, ám korlátozottan diszkrecionális attitüddel felvértezett gazdasági kormányzásra, amely főképpen a keretfeltételek javítására és a kölcsönhatások érvényesítésére törekszik, mintsem hogy számszaki célok elérését erőlteti, túlontúl önhitt intervencionizmussal.

Végső soron a gazellák fejlődését a tudás hasznosításának terepéül szolgáló innovációs ökoszisztéma folyamatainak dinamikus konfigurációja befolyásolja. Ebböl következik, hogy e vállalati létforma természetének jobb megértéséhez rendszerszemléletre, a szélesebb kontextus bekapcsolására és a mélyebb folyamatok dinamikus kölcsönhatásainak feltárására van szükség. Utóbbinak a komplexitást kezelő közgazdaság-tudományi gondolkodás is alapfeltétele.

\section{Hivatkozások}

Admati, A. R. [2019]: Towards a Better Financial System. ECONFIP, Economists for Inclusive Prosperity. Research Brief, https://econfip.org/policy-brief/towards-a-betterfinancial-system/\#.

Ahmad, N.-Ribarsky, J.-Reinsdorf, M. [2017]: Can Potential Mismeasurement of the Digital Economy Explain the Post-Crisis Slowdown in GDP and Productivity Growth? OECD Statistics Working Papers, No. 9. OECD Publishing, Párizs.

Amezcua, A. S.-Grimes, M.-Bradley, S.-Wiklund, J. [2013]: Organizational Sponsorship and Founding Environments: A Contingency View on the Survival of Business Incubated Firms, 1994-2007. Academy of Management Journal, Vol. 56. No. 6. 1628-1654. o. https:// doi.org/10.5465/amj.2011.0652.

Andrews, D.-Criscuolo, C.-Gal, P. A. [2016]: The Global Productivity Slowdown, Technology Divergence and Public Policy. Brookings Institute, Hutchins Center Working Paper, No. 24.

${ }^{42} \mathrm{Az}$ általunk korábban idézett $\mathrm{s}$ az iparpolitikának - a szándékok szintjén - nyomatékot adó Mazzucato [2013] is ebbe a hibába esik. Amikor ugyanis valami jól sült el, azt mindig a gazdasági kormányzás intelligens tervezési képességének tudta be; nem feltételezte, hogy az általa bemutatott technológiai innovációk jószerivel csak az állami jelenlétnek és támogatásnak a későbbi és előre megjósolhatatlan pozitív externáliái voltak. Kiváló kritikáját adja Mazzucato nagyon fölkapott, ám megalapozatlan és parókiális munkájának Mingardi [2015]. 
Arellano, C.-BAI, Y.-Zhang, J. [2012]: Firm Dynamics and Financial Development. Journal of Monetary Economics, Vol. 59. No. 6. 533-549. o. https://doi.org/10.1016/j.jmoneco.2012.06.006. Atkinson, R. D.-Lind, M. [2018]: The Myth of the Roosevelt "Trustbusters". Teddy and FDR weren't the anti-corporate crusaders that they're portrayed as by populists today. The New Republic, május 4. https://newrepublic.com/article/148239/myth-roosevelt-trustbusters.

Bachurov, G. [2013]: Cash Holdings of European Firms. Tilburg University, Tilburg School of Economics and Management, http://arno.uvt.nl/show.cgi?fid=130529.

Bates, T. W.-Kahle, K. M.-Stulz, R. M. [2009]: Why Do U.S. Firms Hold So Much More Cash than They Used To? The Journal of Finance, Vol. 64. No. 5. 1985-2021. o. https://doi. org/10.1111/j.1540-6261.2009.01492.x.

Baumol, W. J.-Panzar, J.-Willig, R. D. [1982]: Contestable markets and the theory of industry structure. Harcourt Brace Jovanovich, New York.

Bennis, W. G.-Nanus, B. [1985]: Leaders: The Strategies for Taking Charge. Harper \& Row, New York.

BIS [2017]: International Banking and Financial Market Developments. BIS Quarterly Review, szeptember. https://www.bis.org/publ/qtrpdf/r_qt1709.pdf.

Bos, J. W. B.-Sta M, E. [2013]: Gazelles and Industry Growth: A Study of Young High-Growth Firms in the Netherlands. Industrial and Corporate Change, Vol. 23. No. 1. 145-169. o. https://doi.org/10.1093/icc/dtt050.

Brown, R.-LeE, N. [2017]: Reluctant Borrowers? Examining the Demand and Supply of Finance for High Growth SMEs in the UK. ICAS Report.

Brys, B.-Perret, S.-Thomas, A.-O’Reilly, P. [2016]: Tax Design for Inclusive Economic Growth. OECD Taxation Working Papers, No. 26. OECD Publishing, Párizs, https://doi. org/10.1787/5jlv74ggk0g7-en.

Burzynski, M.-Deuster, C.-Docquier, F.-De Melo, J. [2019]: Climate Change, Inequality and Human Migration. CEPR Discussion Paper, No. 13997.

Byrne, D. M.-Fernald, J. G.-Reinsdorf, M. B. [2016]: Does the United States have a Productivity Slowdown or a Measurement Problem? Brookings Papers on Economic Activity, 109-182. o. https://doi.org/10.1353/eca.2016.0014.

Cette, G.-Clerk, C.-Bresson, L. [2015]: Contribution of ICT Diffusion to Labour Productivity Growth: The United States, Canada, the Eurozone, and the United Kingdom, 1970-2013. International Productivity Monitor, No. 28. 81-88. o.

Coase, R. H. [2015]: Why Economics Will Change. Man and the Economy, Vol. 2. No. 2. 113-118. o. https://doi.org/10.1515/me-2015-6003.

Colombelli, A.-Krafft, J.-Quatraro, F. [2014]: High Growth Firms and Technological Knowledge: Do Gazelles Follow Exploration or Exploitation Strategies? Industrial and Corporate Change, Vol. 23. No. 1. 261-291. o. https://doi.org/10.1093/icc/dtt053.

Colombelli, A.-Krafft, J.-Quatraro, F. [2019]: Eco-Innovation and Firm Growth: Do Green Gazelles Run Faster? Microeconometric Evidence from a Sample of European Firms. Small Business Economics, 1-19. o. https://doi.org/10.1007/s11187-019-00236-8.

Decker, R. A.-Haltiwanger, J.-Jarmin, R. S.-Miranda, J. [2016]: Where Has All the Skewness Gone? The Decline in High-Growth (Young) Firms in the U.S. European Economic Review, Vol. 86. 4-23. o. https://doi.org/10.1016/j.euroecorev.2015.12.013.

ERC [2019]: Fecundity, Fertility, Survival and Growth: High-Growth Firms in the UK and Their Contribution to Job Creation, a Demographic Perspective. Enterprise Research Centre, Research Paper, No. 74. https://www.enterpriseresearch.ac.uk/wp-content/ uploads/2019/01/ERC-ResPap74-Anyadike-DanesHart-Final.pdf. 
ESRB [2016]: Shedding Lights on Dark Markets. First Insights from the New EU-wide OTC Derivatives Dataset. European Systemic Risk Board, Occasional Paper Series, No. 11. https:// www.esrb.europa.eu/pub/pdf/occasional/20160922_occasional_paper_11.en.pdf.

ESRB [2017]: Mapping the Interconnectedness between EU Banks and Shadow Banking Entities. European Systemic Risk Board, Working Paper, No. 40. https:/eba.europa.eu/sites/default/ documents/files/documents/10180/1431348/5a5b092b-dc8b-4816-89e0-9673bd75d304/ Mapping\%20the\%20interconnectedness\%20between\%20EU\%20banks\%20and\%20 shadow\%20banking\%20entities_paper.pdf?retry=1.

Feeser, H. R.-Willard, G. E. [1989]: Incubators and Performance: A Comparison of High- and Low-Growth High-Tech Firms. Journal of Business Venturing, Vol. 4. No. 6. 429-442. o. https:// doi.org/10.1016/0883-9026(89)90012-8.

Fernald, J. G. [2015]: Productivity and Potential Output before, during, and after the Great Recession. Megjelent: Parker, J. A.-Woodford, M. (szerk.): NBER Macroeconomics Annual 2014. Vol. 29. http://dx.doi.org/10.3386/w20248.

Ferri, G.-Murro, P.-Peruzzi, V.-Rotondi, Z. [2019]: Bank Lending Technologies and Credit Availability in Europe. What Can We Learn from the Crisis? Journal of International Money and Finance, Vol. 95. 128-148. o. https://doi.org/10.1016/j.jimonfin.2019.04.003.

Friedrich, M.-Weik, M. [2019]: Der größte Crash aller Zeiten: Wirtschaft, Politik, Gesellschaft. Wie Sie jetzt noch Ihr Geld schützen können. Eichborn, Köln.

Gantchev, N.-Giannetti, M.-Li, R. [2019]: Does Money Talk? Market Discipline Through Selloffs and Boycotts. European Corporate Governance Institute-Finance Working Paper, No. 634. https://doi.org/10.2139/ssrn.3409455.

Gopinath, G.-Kalemli-Özcan, Ş.-Karabarbounis, L.-Villegas-SancheZ, C. [2017]: Capital Allocation and Productivity in South Europe. The Quarterly Journal of Economics, Vol. 132. No. 4. 1915-1967. o. https://doi.org/10.1093/qje/qjx024.

Hall, B. H.-Helmers, C.-Von Graevenitz, G. [2017]: Technology Entry in the Presence of Patent Thickets. NBER Working Paper, No. 21455. https://doi.org/10.3386/w21455.

Hathaway, I.-Litan, R. [2014]: The Other Aging of America: The Increasing Dominance of Older Firms. Brookings Economic Studies, https://www.brookings.edu/wp-content/uploads/2016/06/ other_aging_america_dominance_older_firms_hathaway_litan.pdf.

Henrekson, M.-Johansson, D. [2008]: Competencies and Institutions Fostering High-Growth Firms. Foundations and Trends in Entrepreneurship, Vol. 5. No. 1. 1-80. o. https://doi. org/10.1561/0300000026.

Jacobs, M.-Mazzucato, M. (szerk.) [2016]: Rethinking Capitalism: Economics and Policy for Sustainable and Inclusive Growth. Political Quarterly Monograph Series. 1. kiadás, WileyBlackwell.

Kalyva, A.-Princen, S.-Leodolter, A.-Astarita, C. [2018]: Labour Taxation and Inclusive Growth. European Commission Directorate-General for Economic and Financial Affairs, https://ec.europa.eu/info/sites/info/files/economy-finance/dp084_en_labour_ taxation_0.pdf.

Kaya, M. C.-Persson, L. [2019]: A Theory of Gazelle Gowth: Competition, Venture Capital Finance and Policy. North American Journal of Economics and Finance, Vol. 50. No. 101019. https://doi.org/10.1016/j.najef.2019.101019.

KIng, M. [2019]: Economic Policy in a World Turned Upside Down. Előadás az IMF éves washingtoni találkozóján, november 23. https://www.imf.org/en/News/Podcasts/AllPodcasts/2019/11/23/mervyn-king. 
KoRNAI JÁNOS [2010]: Innováció és dinamizmus. Kölcsönhatások a rendszerek és a technikai haladás között. Közgazdasági Szemle, 57. évf. 1. sz. 1-36. o.

KovÁcs Olivér [2015]: Stabilitás és dinamizmus. Az innovatív fiskális politika alapjai. Alinea Kiadó, Budapest.

Kovács Olivér [2017]: Az ipar 4.0 komplexitása, I-II. Közgazdasági Szemle, 64. évf. 7-8. és 9. sz. 823-851. o. és 970-987. o. https://doi.org/10.18414/ksz.2017.7-8.823 és https://doi. org/10.18414/ksz.2017.9.970.

Kovács Olivér [2019]: Grounding Complexity Economics in Framing Modern Governance. Acta Oeconomica, Vol. 69. No. 4. 571-594. o.

LeE, J.-HaN, J.-Kim, H.-PARK, J.-K.-LeE, K. [2015]: Role of the Big Business in the GrowthInequality Nexus. https:/editorialexpress.com/cgi-bin/conference/download.cgi?db_ name $=$ WCCE2015\&paper_id $=198$.

Levy-Yeyati, E.-Montané, M.-Sartorio, L. [2019]: What Works for Active Labor Market Policies? Harvard University Center for International Development, Faculty Working Paper, No. 358. https:/growthlab.cid.harvard.edu/files/growthlab/files/2019-07-cid-wp358-labor-market-policies.pdf.

Marchese, M. [2016]: High-Growth Firms: Why They Matter and What Public Policy Can Do. Public Administration Review, Vol. 76. No. 2. 239-240. o. The American Society for Public Administration. https://doi.org/10.1111/puar.12492.

Mas-Verdú, F.-Ribeiro-Soriano, D.-Roig-Tierno, N. [2015]: Firm Survival: The Role of Incubators and Business Characteristics. Journal of Business Research, Vol. 68. No. 4. $793-$ 796. o. https://doi.org/10.1016/j.jbusres.2014.11.030.

Mazzucato, M. [2013]: The Entrepreneurial State: Debunking Public vs. Private Sector Myths. Anthem Other Canon Economics. 1. kiadás, Anthem Press, http://www.looooker. com/wp-content/uploads/2015/05/The-Entrepreneurial-State-Debunking-Public-vs.Private-Sector-Myths.pdf.

McGowan, M. A.-Andrews, D. [2015]: Labour Market Mismatch and Labour Productivity. Evidence from PIAAC Data. OECD Economics Department Working Papers, http:// www.oecd.org/economy/growth/Labour-Market-Mismatch-and-Labour-ProductivityEvidence-from-PIAAC-Data.pdf.

Mingardi, A. [2015]: A Critique of Mazzucato's Entrepreneurial State. Cato Journal, Vol. 35. No. 3. 603-625. o.

OECD [2013]: An International Benchmarking Analysis of Public Programmes for High Growth Firms. OECD Publishing, Párizs, https://www.oecd.org/cfe/leed/OECD-DBA\%20 HGF\%20PROGRAMME\%20REPORT_SECOND\%20FINAL\%20DRAFT\%20(2).pdf.

OECD [2017a]: Entrepreneurship at a Glance 2017. OECD Publishing, Párizs, https://www. oecd-ilibrary.org/employment/entrepreneurship-at-a-glance-2017_entrepreneur_aag2017-en.

OECD [2017b]: Financing SMEs and Entrepreneurs 2017. OECD Scoreboard. OECD Publishing, Párizs, https:/www.oecd.org/cfe/smes/Financing\%20SMEs\%20and\%20Entrepreneurs\%202017_Highlights.pdf.

OECD [2018]: Promoting Innovation in Established SMEs. OECD Policy Note, SME Ministerial Conference, február 22-23. Mexikóváros. 4. párhuzamos szekció. Elérhető: https://www. oecd.org/cfe/smes/ministerial/documents/2018-SME-Ministerial-Conference-ParallelSession-4.pdf.

OECD [2019]: Under Pressure: The Squeezed Middle Class. OECD Publishing, Párizs, https:// www.oecd.org/els/soc/OECD-middle-class-2019-main-findings.pdf. 
Ogburn, W. F. [1922]: Social Change with Respect to Culture and Original Nature. Viking Press, New York.

Oxford Economics [2019]: SME Pulse 2019. Strategies to Boost the Bottom Line. A Global Study to Investigate How SMEs are Adapting to Disruption and Economic Uncertainty in 2019 and Beyond. Oxford Economics, https://www.oxfordeconomics.com/publication/ download/310989.

Ravallion, M.-Chen, S. [2017]: Welfare-Consistent Global Poverty Measures. NBER Working Paper, No. 23739. https://doi.org/10.3386/w23739.

Ro, S. [2014]: The Rate of Share Buybacks Has Doubled in the Last Decade. Business Insider, április 5. https://www.businessinsider.com/sp-500-stock-buyback-history-2014-4.

SAgE [2017]: Becoming a People Company - The Way to Unlock Fast Track Growth. Sage People Research Report, Atlanta, https:/www.sagepeople.com/wp-content/themes/ fairsail/includes/redirect.php?pdf $=17828$.

Sass Magdolna [2019]: Jobb ma egy veréb, mint holnap egy túzok. Alternatív növekedési utak keresése a visegrádi országokban. Előadás, 2019. december 20. MTA Világgazdasági Tudományos Tanács kilencedik ülése.

Shuman, J. C.-Shaw, J. J.-Sussman, G. [1985]: Strategic Planning in Smaller Rapid Growth Companies. Long Range Planning, Vol. 18. No. 6. 48-53. o. https://doi.org/10.1016/00246301(85)90063-9.

Skidelsky, R. [2018]: Money and Government: The Past and Future of Economics. Yale University Press.

Sorin, G. A. [2019]: Leverage and Firm Growth: An Empirical Investigation of Gazelles from Emerging Europe. International Entrepreneurship and Management Journal, Springer, Vol. 15. No. 1. 209-232. o. http://dx.doi.org/10.1007/s11365-018-0524-5.

Sovinsky, M.-Eizenberg, A.-Pechy, A. [2016]: Technology Adoption, Vertical Restraints and Partial Foreclosure: Changing the Structure of an Industry. Annual Conference 2016 (Augsburg): Demographic Change, No. 145680.

Spitz-Oener, A. [2006]: Technical Change, Job Tasks, and Rising Educational Demands: Looking Outside the Wage Structure. Journal of Labor Economics, Vol. 24. No. 2. 235-270. o. https://doi.org/10.1086/499972.

Standing, G. [2016]: The Precariat: The New Dangerous Class. 4. kiadás, Bloomsbury, London.

Teulings, C.-Baldwin, R. (szerk.) [2014]: Secular Stagnation: Facts, Causes and Cures. VOXEU.org, https://voxeu.org/content/secular-stagnation-facts-causes-and-cures.

Thiel, P. [2014]: If you want to create and capture lasting value, look to build a monopoly. Wall Street Journal, szeptember 12. https://www.wsj.com/articles/peter-thiel-competitionis-for-losers-1410535536.

UBS [2019]: UBS Global Real Estate Bubble Index. UBS, https:/www.ubs.com/content/dam/static/ emailer/2019/sept/BR-108576/global-real-estate-bubble-index-2019-global-version.pdf.

Vacas-Soriano, C.-FernándeZ-Macías, E. [2017]: Income Inequalities and Employment Patterns in Europe Before and After the Great Recession. Eurofound, EF1663, No. 70. https://www.eurofound.europa.eu/sites/default/files/ef_publication/field_ef_document/ ef1663en.pdf.

VASAGAR, J. [2017]: Singapore tech start-ups face years of struggle. Government support means 'zombie' businesses continue with low sales and few staff. The Financial Times, szeptember 13. https://www.ft.com/content/c9892022-318c-11e7-9555-23ef563ecf9a.

Wolf, M. [2019]: The Crisis of the Liberal Global Order. Workshop-előadás, NAEC OECD, november 20. Párizs. 